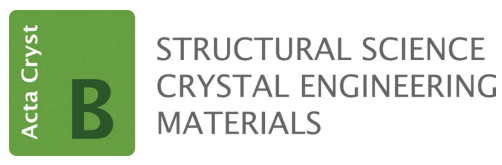

ISSN 2052-5206

Received 2 June 2018

Accepted 29 August 2018

Edited by J. Lipkowski, Polish Academy of Sciences, Poland

Keywords: modular structure; antiperovskite layers; aravaite; disorder; diffuse scattering.

CCDC reference: 1864463

Supporting information: this article has supporting information at journals.iucr.org/b

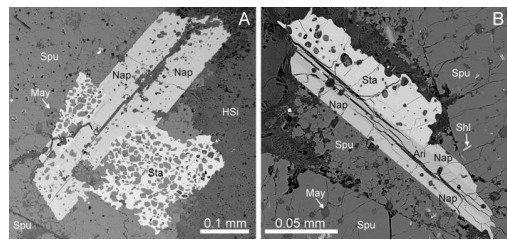

(C) 2018 International Union of Crystallography

\section{Aravaite, $\mathrm{Ba}_{2} \mathrm{Ca}_{18}\left(\mathrm{SiO}_{4}\right)_{6}\left(\mathrm{PO}_{4}\right)_{3}\left(\mathrm{CO}_{3}\right) \mathrm{F}_{3} \mathrm{O}$ : modular structure and disorder of a new mineral with single and triple antiperovskite layers}

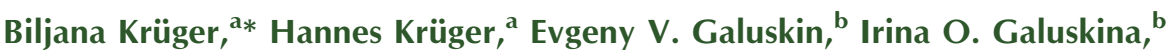 \\ Yevgeny Vapnik, ${ }^{c}$ Vincent Olieric ${ }^{\mathrm{d}}$ and Anuschka Pauluhn ${ }^{\mathrm{d}}$
}

\begin{abstract}
anstitute of Mineralogy and Petrography, University of Innsbruck, Innrain 52, Innsbruck, 6020, Austria, ${ }^{\mathbf{b}}$ Department of Geochemistry, Mineralogy and Petrography, University of Silesia, Będzińska 60, Sosnowiec, 41-200, Poland,

${ }^{\mathbf{c}}$ Department of Geological and Environmental Sciences, Ben-Gurion University of the Negev, PO Box 653, Beer-Sheva, 84105, Israel, and ${ }^{\mathbf{d}}$ Paul Scherrer Institute, Swiss Light Source, Villigen, 5232, Switzerland. *Correspondence e-mail: biljana.krueger@uibk.ac.at
\end{abstract}

The crystal structure of the new mineral aravaite $\mathrm{Ba}_{2} \mathrm{Ca}_{18}$ $\left(\mathrm{SiO}_{4}\right)_{6}\left(\mathrm{PO}_{4}\right)_{3}\left(\mathrm{CO}_{3}\right) \mathrm{F}_{3} \mathrm{O}[R \overline{3} m, a=7.12550(11), c=66.2902$ (13) $\AA, \quad V=$ $2914.81(8) \AA^{3}, Z=3$ ] was solved from single-crystal diffraction data, collected using synchrotron radiation at the X06DA beamline of the Swiss Light Source. The unit cell of this modular mineral contains six layers of $\left\{\mathrm{Ba}\left(\mathrm{PO}_{4}\right)_{1.5}\left(\mathrm{CO}_{3}\right)_{0.5}\right\}^{3.5-}$ (T-layer), three triple antiperovskite layers (tAP) $\left\{\left(\mathrm{F}_{2} \mathrm{OCa}_{12}\right)\left(\mathrm{SiO}_{4}\right)_{4}\right\}^{4+}$, and three single antiperovskite layers (sAP) $\left\{\left(\mathrm{FCa}_{6}\right)\left(\mathrm{SiO}_{4}\right)_{2}\right\}^{3+}$. The structure refinement confirms a model with a layer sequence of T-sAP-T-tAP as an average structure of this mineral. However, one-dimensional diffuse scattering observed parallel to $\mathbf{c}^{*}$ implies imperfections in the stacking sequence of the average structure. Qualitative modelling of disorder confirms that the alternating sequence of T-sAP and T-tAP blocks is disturbed. The blocks occurring in this new mineral are known from other socalled hexagonal intercalated antiperovskite structures: T-sAP (stracherite and zadovite group), T-tAP (ariegilatite and nabimusaite group).

\section{Introduction}

Hexagonal antiperovskites are inorganic compounds built from units of anion-centred octahedra. Their structure can be considered as polytypic variations of the cubic perovskite structure, for example, as structures corresponding to the $2 \mathrm{H}$, $4 \mathrm{H}$ and 9R polytypes reported by Gäbler \& Niewa (2007). Many minerals can be described using antiperovskite units composed of face- and corner-sharing octahedra (Krivovichev, 2007, 2009). As they are not exclusively built from cornersharing octahedra they are not considered as members of the perovskite supergroup (Mitchell et al., 2017). Additionally, some minerals show antiperovskite modules, which are intercalated with intermediate ions and complexes (Krivovichev, 2007). The diversity of modular structures is well represented in the intercalated (or broken) antiperovskite minerals of the arctite supergroup (Galuskin et al., 2018a). This supergroup combines silicate minerals of the nabimusaite group (Galuskin et al., 2015a, 2018c; Galuskina et al., 2018) and zadovite group (Galuskin et al., 2015b, 2017, 2018b). The entire supergroup is characterized by modular structures containing single antiperovskite (sAP) layers of composition $\left\{\left[W B_{6}\right]\left(T \mathrm{O}_{4}\right)_{2}\right\}$, triple antiperovskite (tAP) layers $\left\{\left[W_{3} B_{12}\right]\left(T \mathrm{O}_{4}\right)_{4}\right\}$, and tetrahedral (T) layers $A\left(\mathrm{TO}_{4}\right)_{2}$, where $A=\mathrm{Ba}, \mathrm{K}, \mathrm{Sr} \ldots ; B=\mathrm{Ca}, \mathrm{Na} \ldots$; $T=\mathrm{Si}, \mathrm{P}, \mathrm{V}^{5+}, \mathrm{S}^{6+}, \mathrm{Al} \ldots ; W=\mathrm{O}^{2-}, \mathrm{F}^{-}$. The aforementioned 


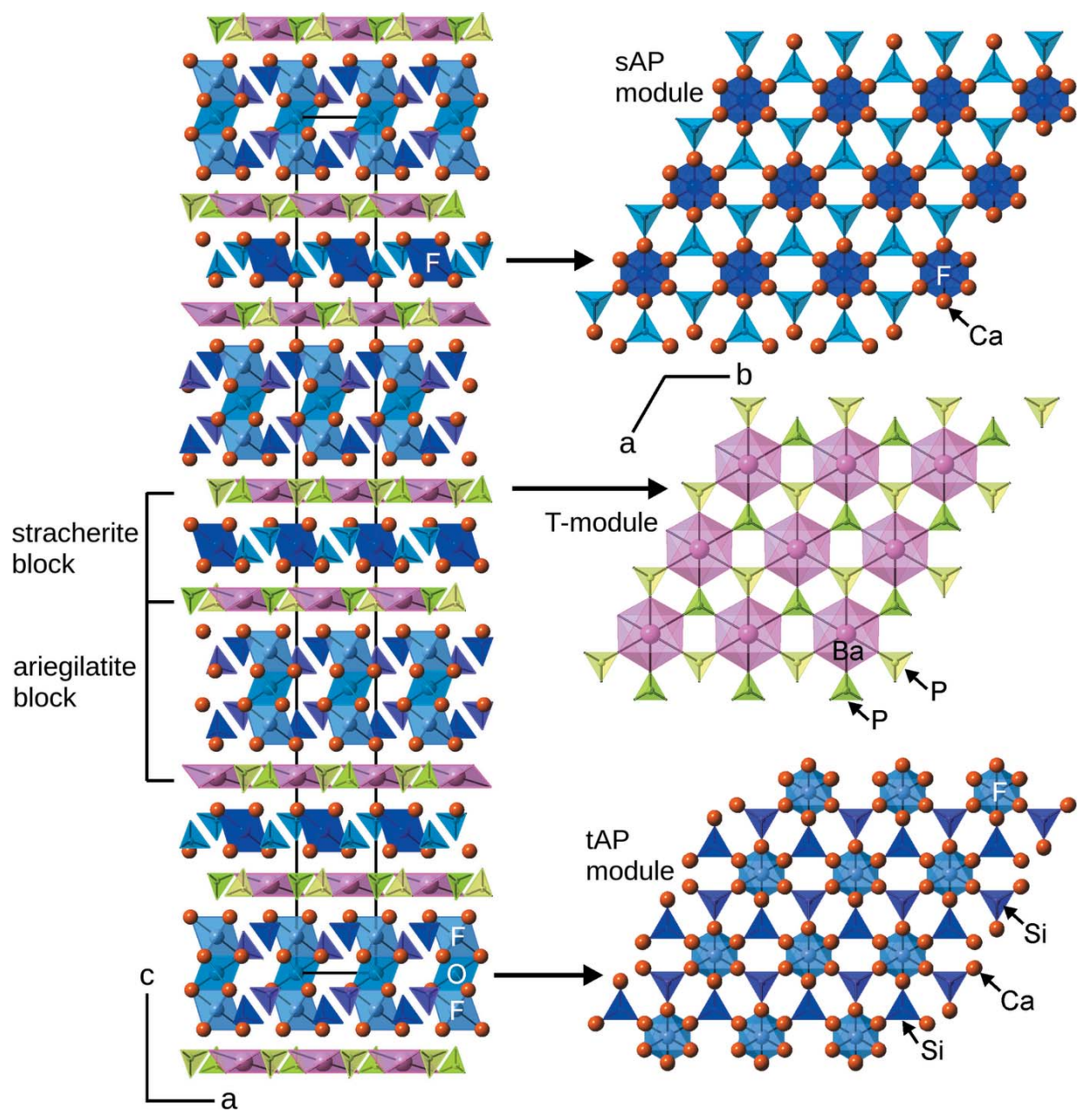

Figure 1

The structure of aravaite consisting of blocks of ariegilatite and stracherite. The structure is formed by ordered intercalation of T-modules $=\left\{\mathrm{Ba}\left(\mathrm{PO}_{4}\right)_{1.5}\left(\mathrm{CO}_{3}\right)_{0.5}\right\}^{3.5-}$ with antiperovskite layers of two types: tAP (triple antiperovskite module) $=\left\{\left(\mathrm{F}_{2} \mathrm{OCa}_{12}\right)\left(\mathrm{SiO}_{4}\right)_{4}\right\}^{4+}$ and sAP $=\left\{\left(\mathrm{FCa}_{6}\right)\left(\mathrm{SiO}_{4}\right)_{2}\right\}^{3+}($ single antiperovskite module) in the sequence of T-sAP-T-tAP- ... .
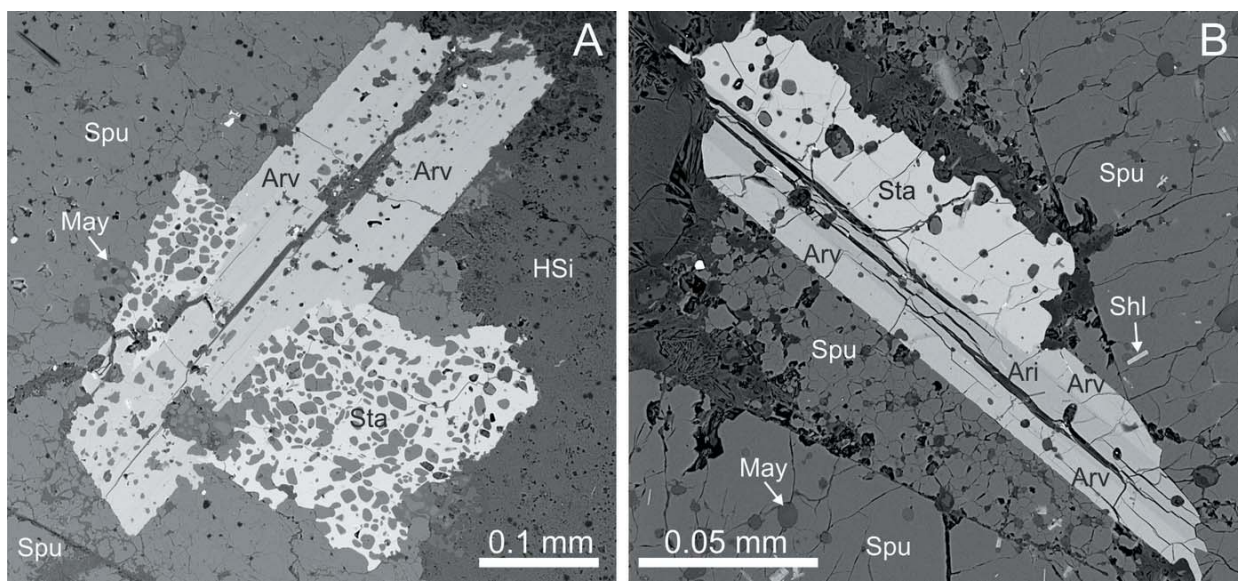

Figure 2

SEM micrographs (backscattered electron mode). (a) Aravaite intergrown with stracherite. A fragment of this crystal was used for the structural study. This is a rare example of spurrite marble, in which ariegilatite is absent. (b) Epitaxial intergrowth of three intercalated antiperovskites: aravaite, ariegilatite and stracherite. Arv is aravaite, Ari is ariegilatite, HSi is undiagnosed hydrosilicates, May is fluormayenite-fluorkyuygenite, $\mathrm{Shl}$ is shulamitite, Spu is spurrite, Sta is stracherite. layers are shown in Fig. 1. Minerals of the zadovite group contain sAP layers, whereas tAP layers are observed in minerals of the nabimusaite group. The units addressed as layers above may also be denoted as modules using the modular classification (Ferraris et al., 2004).

Taking the chemical composition into account, we can describe the structure of the new intercalated antiperovskite mineral with alternating blocks of ariegilatite $\mathrm{BaCa}_{12}-$ $\left(\mathrm{SiO}_{4}\right)_{4}\left(\mathrm{PO}_{4}\right)_{2} \mathrm{~F}_{2} \mathrm{O}$ (Galuskin et al., 2018c) and stracherite $\mathrm{BaCa}_{6-}^{-}$ $\left(\mathrm{SiO}_{4}\right)_{2}\left[\left(\mathrm{PO}_{4}\right)\left(\mathrm{CO}_{3}\right)\right] \mathrm{F}$ (Galuskin et al., 2018b). These two minerals belong to the nabimusaite and zadovite groups, respectively. All of the mentioned structures show $R$ centred trigonal unit cells. Nabimusaite-group minerals with a sequence of T-tAP $(3 \times)$ have a lattice parameter $c$ of roughly $41 \AA$. The sequence T-sAP $(3 x)$ as found in zadovite-group minerals sums up to $c \simeq 26 \AA$. The larger $c$ parameter of circa $66 \AA$ observed in aravaite is the sum of the sequence T-sAP-T$\operatorname{tAP}(3 \times)$.

\section{Occurrence}

Aravaite (IMA 2018-078) was found in pyrometamorphic spurrite rocks of the Hatrurim Complex in the Negev Desert (31 ${ }^{\circ} 13^{\prime} 58^{\prime \prime}$ N, $35^{\circ} 16^{\prime} 2^{\prime \prime}$ E) near Arad, Israel. These pyrometamorphic rocks are represented by spurrite marbles, larnite pseudoconglomerates, gehlenite hornfelses and different paralavas, occurring widely along the rift zone of the Dead Sea (Bentor, 1960; Gross, 1977; Vapnik et al., 2007; Sokol et al., 2008; Galuskina et al., 2014). Associated minerals are spurrite, calcite, brownmillerite, shulamitite, $\mathrm{CO}_{3^{-}}$ bearing fluorapatite, brucite, fluormayenite-fluorkyuygenite, periclase, barytocalcite and baryte. Moreover, in the same rock samples, two other new minerals with antiperovskite modules were found: stracherite, $\quad \mathrm{BaCa}_{6}\left(\mathrm{SiO}_{4}\right)_{2}\left[\left(\mathrm{PO}_{4}\right)\right.$ $\left.\left(\mathrm{CO}_{3}\right)\right] \mathrm{F}$, a mineral with single antiperovskite (sAP) layers (Galuskin et 
Table 1

Chemical composition as averaged from 41 (aravaite), 42 (stracherite) and eight (ariegilatite) spot measurements.

Note, that $T 1$ and $T 2$ denote the total of tetrahedral sites in the antiperovskite- and in the T-layers, respectively.

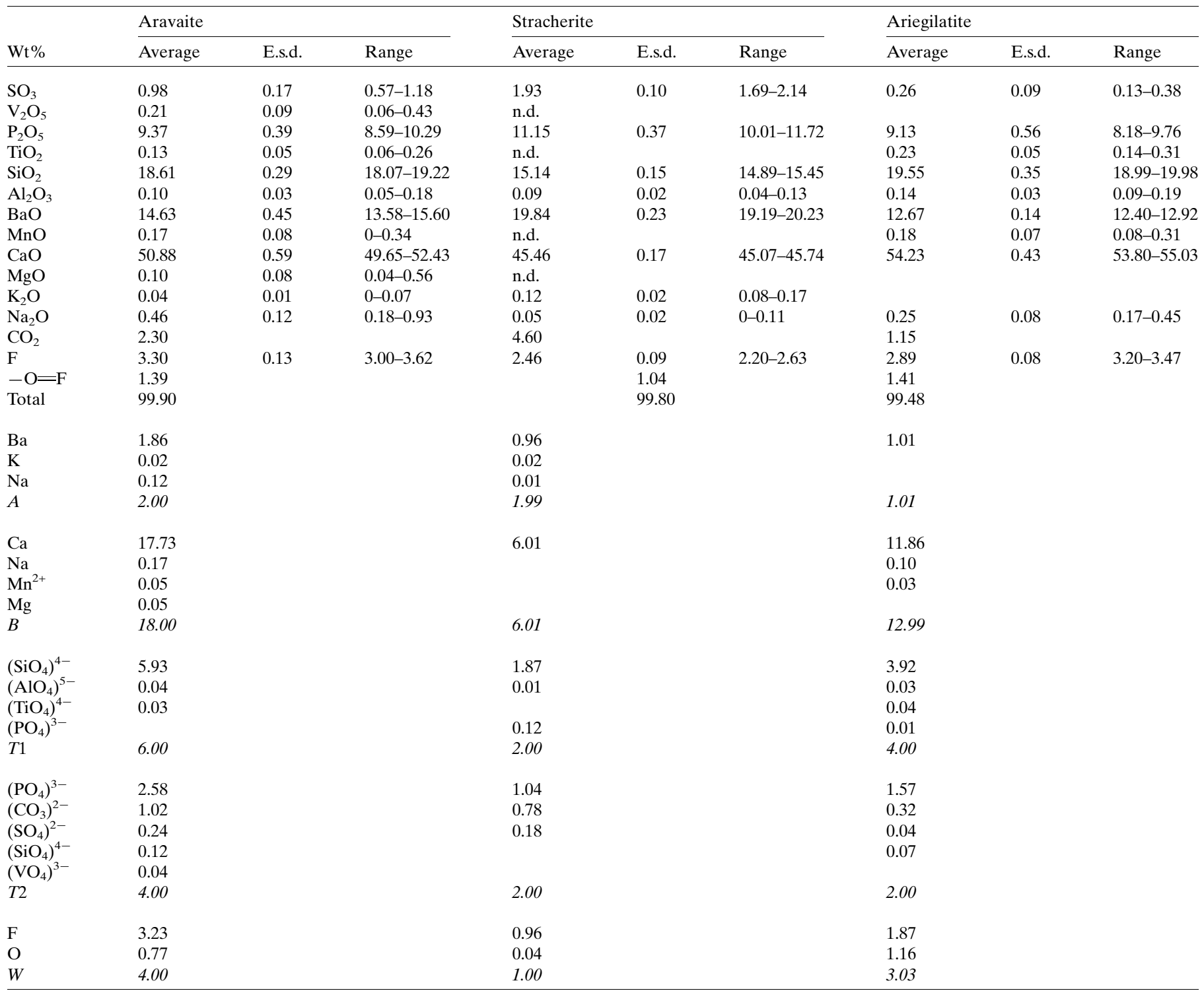

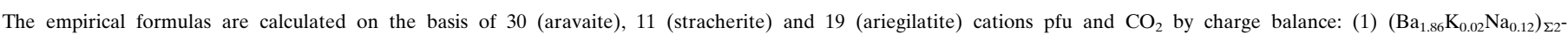

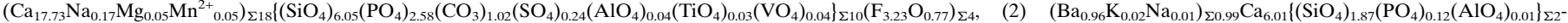
$\left\{\left(\mathrm{PO}_{4}\right)_{1.04}\left(\mathrm{CO}_{3}\right)_{0.78}\left(\mathrm{SO}_{4}\right)_{0.18}\right\}_{\Sigma 2}\left(\mathrm{~F}_{0.96} \mathrm{O}_{0.04}\right)_{\Sigma 1}$ and (3) $\left.\mathrm{Ba}_{1.01}\left(\mathrm{Ca}_{11.86} \mathrm{Na}_{0.10} \mathrm{Mn}^{2+}{ }_{0.03}\right)_{\Sigma 11.99}\left(\mathrm{SiO}_{4}\right)_{3.92}\left(\mathrm{PO}_{4}\right)_{0.01}\left(\mathrm{AlO}_{4}\right)_{0.03}\left(\mathrm{TiO}_{4}\right)_{0.04}\right\}_{\Sigma 4}\left\{\left(\mathrm{PO}_{4}\right)_{1.57}\left(\mathrm{CO}_{3}\right)_{0.32}\left(\mathrm{SO}_{4}\right)_{0.04} \mathrm{~V}_{0.07}\right\}_{\Sigma 2}\left(\mathrm{~F}_{1.87} \mathrm{O}_{1.16}\right)_{\Sigma 3.03}$.

al., 2018b), and ariegilatite, $\mathrm{BaCa}_{12}\left(\mathrm{SiO}_{4}\right)_{4}\left(\mathrm{PO}_{4}\right)_{2} \mathrm{~F}_{2} \mathrm{O}$, with triple antiperovskite (tAP) layers (Galuskin et al., 2018c). Rare grains of aravaite were detected as epitaxial intergrowth with stracherite or/and ariegilatite crystals [Figs. 2(a) and $2(b)]$. Further details on the occurrence of these minerals are given by Galuskin et al. $(2018 b, c)$.

\section{Methods of investigation}

The morphology and chemical composition of aravaite and associated minerals were studied using optical microscopy, a scanning electron microscope Phenom XL, an electron microprobe analyser and a micro-Raman spectrometer. The crystal structure was solved from synchrotron diffraction data.

\subsection{Chemical analysis}

Quantitative chemical analyses were performed using a CAMECA SX100 microprobe analyser (Institute of Geochemistry, Mineralogy and Petrology, University of Warsaw, Poland) at $15 \mathrm{kV}$ and $10 \mathrm{nA}$, using the following lines and standards: $\mathrm{Ba} L \alpha, \mathrm{S} K \alpha$-baryte; $\mathrm{P} K \alpha$-apatite; $\mathrm{Ca} K \alpha$ wollastonite; $\operatorname{Mg} K \alpha$, Si $K \alpha$-diopside; Fe $K \alpha$-hematite, $\mathrm{Al} K \alpha$, K $K \alpha$-orthoclase; Ti $K \alpha$-rutile; $\mathrm{Na} K \alpha$-albite, $\mathrm{Sr} L \alpha-\mathrm{SrTiO}_{3}$ and $\mathrm{F} K \alpha$-fluorphlogopite. Results are given in Table 1. 


\subsection{Raman spectroscopy}

Raman spectra of the new mineral aravaite, stracherite and ariegilatite were recorded on a WITec alpha 300R Confocal Raman Microscope (Department of Earth Science, University of Silesia, Sosnowiec, Poland) equipped with an air-cooled solid-state laser $(532 \mathrm{~nm})$ and a CCD camera operating at $-61^{\circ} \mathrm{C}$. The laser radiation was coupled to a microscope through a single-mode optical fibre with a diameter of $3.5 \mu \mathrm{m}$. An air Zeiss LD EC Epiplan-Neofluan DIC-100/0.75NA objective was used. Raman-scattered light was focused on a broad-band single-mode fibre with an effective pinhole size of about $30 \mu \mathrm{m}$. A monochromator with a $600 \mathrm{~mm}^{-1}$ grating was used. The power of the laser at the sample position was $\sim 40 \mathrm{~mW}$. An integration time of $5 \mathrm{~s}$, with an accumulation of 15-20 scans and a resolution of $3 \mathrm{~cm}^{-1}$ were chosen. A standard measurement was performed using the Raman scattering line of a silicon plate $\left(520.7 \mathrm{~cm}^{-1}\right)$. Fitting of spectra was performed with the help of the GRAMS/AI (Thermo Fisher Scientific) program using the mixed Lorentz-Gauss function.

\subsection{Structural analysis}

Single-crystal synchrotron radiation diffraction experiments were performed at the X06DA beamline at the Swiss Light Source (Paul Scherrer Institute, Villigen, Switzerland). The beamline is equipped with a multi-axis goniometer PRIGo (Waltersperger et al., 2015) and a PILATUS 2M-F detector. Diffraction experiments were performed at ambient conditions using the $D A+$ (Wojdyla et al., 2018) acquisition software. The radiation source is a SLS super-bending magnet (2.9 T). A wavelength of $\lambda=0.70848 \AA$ is obtained using a Bartels monochromator. The detector was placed $120 \mathrm{~mm}$ from the sample, with a vertical offset of $67 \mathrm{~mm}$, resulting in a maximum resolution of $0.7 \AA$. A total of 1800 frames were recorded using a fine-sliced $\left(0.1^{\circ}\right) \omega$-scan at 0.1 seconds per frame (crystal A). Experimental details are given in Table 2. Lattice parameters were determined using CrysAlisPro (Rigaku, 2016); the data reduction was processed with $X D S$ (Kabsch, 2010). The original images of the diffraction data collection show evidence of one-dimensional diffuse scattering. Two further crystals $(\mathrm{B}, \mathrm{C})$ with different intensity patterns on the diffuse lines were re-measured to collect diffuse scattering data. These experiments were also performed at the SLS (beamline X06DA); however, this time an Aerotech one-circle goniometer was used. The detector was moved to a distance of $80 \mathrm{~mm}$ (with no vertical offset) and an exposure time of $0.6 \mathrm{~s}$ was used for each frame of $0.1^{\circ} \omega$ rotation. To further investigate the distribution and orientation of the diffuse intensities within the reciprocal space, the orienting matrix was determined using $X D S$ (Kabsch, 2010), and subsequently layers of the reciprocal space were reconstructed using a modified version of Xcavate (Estermann \& Steurer, 1998). Line profiles were extracted from the reconstructed layers with ImageJ (Schneider et al., 2012).
Table 2

Experimental details.

\begin{tabular}{|c|c|}
\hline \multicolumn{2}{|l|}{ Crystal data } \\
\hline Chemical formula & $\mathrm{C}_{0.919} \mathrm{Ba}_{2} \mathrm{Ca}_{17.621} \mathrm{~F}_{3.462} \mathrm{Na}_{0.379} \mathrm{O}_{39.7} \mathrm{P}_{2.96} \mathrm{Si}_{6}$ \\
\hline$M_{\mathrm{r}}$ & 1961.8 \\
\hline Crystal system, space group & Trigonal, $R \overline{3} m$ \\
\hline Temperature (K) & 293 \\
\hline$a, c(\AA)$ & $7.12550(11), 66.2902(13)$ \\
\hline$V\left(\AA^{3}\right)$ & $2914.81(8)$ \\
\hline$Z$ & 3 \\
\hline Radiation type, wavelength ( & Synchrotron, $\lambda=0.70848$ \\
\hline$\mu\left(\mathrm{mm}^{-1}\right)$ & 4.701 \\
\hline Crystal size $(\mathrm{mm})$ & $0.06 \times 0.03 \times 0.03$ \\
\hline \multicolumn{2}{|l|}{ Data collection } \\
\hline Diffractometer & Pilatus 2M-F \\
\hline Absorption correction & $\begin{array}{l}\text { Empirical (using intensity } \\
\text { measurements) }\end{array}$ \\
\hline $\begin{array}{l}\text { No. of measured, independent } \\
\text { and observed }[I>3 \sigma(I)] \\
\text { reflections }\end{array}$ & $5677,1291,1145$ \\
\hline$R_{\text {int }}$ & 0.049 \\
\hline$(\sin \theta / \lambda)_{\max }\left(\AA^{-1}\right)$ & 0.749 \\
\hline \multicolumn{2}{|l|}{ Refinement } \\
\hline$R\left[F^{2}>2 \sigma\left(F^{2}\right)\right], w R\left(F^{2}\right), S$ & $0.082,0.183,3.60$ \\
\hline No. of reflections & 1291 \\
\hline No. of parameters & 85 \\
\hline$\Delta \rho_{\max }, \Delta \rho_{\min }\left(\mathrm{e} \AA^{-3}\right)$ & $12.08,-2.45$ \\
\hline
\end{tabular}

Crystal data

cormula

Crystal system, space group

Temperature (K)

$a, c(\AA)$

Z

Radiation type, wavelength (A)

$\mu\left(\mathrm{mm}^{-1}\right)$

Data collection

Diffractomete

$[I>3 \sigma(I)]$

$R_{\text {int }}$

Refinement

$R\left[F^{2}>2 \sigma\left(F^{2}\right)\right], w R\left(F^{2}\right), S$

No. of parameter

$\Delta \rho_{\max }, \Delta \rho_{\min }\left(\mathrm{e}^{-3}\right)$

\author{
${ }_{7.7} \mathrm{P}_{2.96} \mathrm{Si}_{6}$ \\ 293 \\ rotron, $\lambda=0.70848$ \\ .701
}

latus 2M-F

pirical (using intensity

measurements

\section{Results}

\subsection{Morphology and composition of the new antiperovskite}

Results of chemical analyses (Table 1) and Raman spectroscopy (Fig. 3) show that the minerals stracherite, ariegilatite and aravaite are closely related. All three minerals can be seen together in a backscattered electron (BSE) image of spurrite marble (Fig. 2b). The morphology of the aggregates indicates oriented, i.e. epitaxial, intergrowth. Aravaite appears brighter than ariegilatite and darker than stracherite. It crystallizes after ariegilatite and is often overgrown later by stracherite (Fig. 2b). The new antiperovskite exhibits an homogeneous chemical composition and the content of main oxides shows values between stracherite and ariegilatite (Table 1). Its empirical formula is $\left(\mathrm{Ba}_{1.86} \mathrm{~K}_{0.02} \mathrm{Na}_{0.12}\right)_{\Sigma 2}\left(\mathrm{Ca}_{17.73} \mathrm{Na}_{0.17} \mathrm{Mg}_{0.05^{-}}\right.$ $\left.\mathrm{Mn}^{2+}{ }_{0.05}\right)_{\Sigma 18}\left(\mathrm{SiO}_{4}\right)_{6.05}\left(\mathrm{PO}_{4}\right)_{2.58}\left(\mathrm{CO}_{3}\right)_{1.02}\left(\mathrm{SO}_{4}\right)_{0.24}\left(\mathrm{AlO}_{4}\right)_{0.04}{ }^{-}$ $\left.\left(\mathrm{TiO}_{4}\right)_{0.03}\left(\mathrm{VO}_{4}\right)_{0.04}\right\}_{\Sigma 10}\left(\mathrm{~F}_{3.23} \mathrm{O}_{0.77}\right)_{\Sigma 4}$ and this can be simplified to $\mathrm{Ba}_{2} \mathrm{Ca}_{18}\left[\left(\mathrm{SiO}_{4}\right)_{6}\left(\mathrm{PO}_{4}\right)_{3}\left(\mathrm{CO}_{3}\right)\right] \mathrm{F}_{3} \mathrm{O}$.

The Raman spectrum of aravaite is similar to spectra of ariegilatite and stracherite (Fig. 3). This is well recognizable from the example of the symmetric stretching $v_{1}$ vibrations in $\left(\mathrm{SiO}_{4}\right)^{4-}$. In the Raman spectrum of aravaite, three main bands are distinguished: 829,852 and $877\left(\mathrm{~cm}^{-1}\right)$. The first and third bands have analogues in the spectrum of ariegilatite and the second band $\left(852 \mathrm{~cm}^{-1}\right)$ corresponds to the $859 \mathrm{~cm}^{-1}$ band in the stracherite spectrum. Consequently, it is reasonable to assume the presence of the two types of antiperovskite layer (tAP and sAP) in the structure of the new mineral. In the spectrum of aravaite, as well as in the stracherite spectrum, there is a strong band related to stretching vibrations of $v_{1}$ 
Table 3

Atomic coordinates of aravaite.

\begin{tabular}{lllllll}
\hline $\begin{array}{l}\text { Atom } \\
\text { site }\end{array}$ & $\begin{array}{l}\text { Atom } \\
\text { type }\end{array}$ & $\begin{array}{l}\text { Occu- } \\
\text { pation }\end{array}$ & $x$ & $y$ & $z$ & $U_{\text {iso }}$ \\
\hline Ba1 & $\mathrm{Ba}$ & 1 & 0 & 0 & $0.270337(10)$ & $0.0140(3)$ \\
$\mathrm{Ca} 1$ & $\mathrm{Ca}$ & 1 & $0.49749(8)$ & $0.99499(16)$ & $0.23253(2)$ & $0.0066(4)$ \\
$\mathrm{Ca} 2$ & $\mathrm{Ca}$ & 1 & $0.98845(19)$ & $0.49422(9)$ & $0.30918(2)$ & $0.0086(4)$ \\
$\mathrm{Ca} 3$ & $\mathrm{Ca}$ & $0.937(12)$ & $0.48954(9)$ & $0.97909(18)$ & $0.146883(19)$ & $0.0058(4)$ \\
$\mathrm{Na} 3$ & $\mathrm{Na}$ & $0.063(12)$ & $0.48954(9)$ & $0.97909(18)$ & $0.146883(19)$ & $0.0058(4)$ \\
$T 1$ & $\mathrm{Si}$ & 1 & 0.6667 & 0.3333 & $0.19130(4)$ & $0.0022(5)$ \\
$T 2$ & $\mathrm{Si}$ & 1 & 0.3333 & 0.6667 & $0.34596(4)$ & $0.0015(5)$ \\
T3 & $\mathrm{Si}$ & 1 & 0 & 0 & $0.21838(4)$ & $0.0022(5)$ \\
$T 4$ & $\mathrm{P}$ & $0.940(12)$ & 0.6667 & 0.3333 & $0.26572(5)$ & $0.0063(8)$ \\
T5p & $\mathrm{P}$ & $0.54(2)$ & 0.3333 & 0.6667 & $0.27450(7)$ & $0.0071(13)$ \\
T5c & $\mathrm{C}$ & $0.46(2)$ & 0.3333 & 0.6667 & $0.27450(7)$ & $0.0071(13)$ \\
O1 & $\mathrm{O}$ & $0.865(14)$ & $0.2223(4)$ & $0.7777(4)$ & $0.28273(8)$ & $0.017(2)$ \\
O2 & $\mathrm{O}$ & 1 & 0.3333 & 0.6667 & $0.25243(12)$ & $0.012(2)$ \\
O3 & $\mathrm{O}$ & 1 & $0.4578(4)$ & $0.9155(7)$ & $0.35310(8)$ & $0.0193(16)$ \\
O4 & $\mathrm{O}$ & 1 & 0.6667 & 0.3333 & $0.28903(12)$ & $0.0103(19)$ \\
O5 & $\mathrm{O}$ & 1 & $0.5421(3)$ & $0.0842(7)$ & $0.18354(7)$ & $0.0101(8)$ \\
O6 & $\mathrm{O}$ & 1 & 0.3333 & 0.6667 & $0.32173(13)$ & $0.018(2)$ \\
O7 & $\mathrm{O}$ & 1 & 0.6667 & 0.3333 & $0.21597(11)$ & $0.0088(19)$ \\
O8 & $\mathrm{O}$ & 1 & $0.7482(6)$ & $0.8741(3)$ & $0.22475(7)$ & $0.0111(14)$ \\
O9 & $\mathrm{O}$ & 1 & $0.7834(3)$ & $0.2166(3)$ & $0.25706(6)$ & $0.0114(14)$ \\
O10 & $\mathrm{O}$ & 1 & 0 & 0 & $0.19203(11)$ & 0.003087 \\
O11 & $\mathrm{O}$ & $0.53(16)$ & 0.3333 & 0.6667 & 0.1667 & $0.002(2)$ \\
F1 & $\mathrm{F}$ & $0.47(16)$ & 0.3333 & 0.6667 & 0.1667 & $0.002(2)$ \\
F2 & $\mathrm{F}$ & 1 & 0.6667 & 0.3333 & 0.3333 & $0.013(2)$ \\
F3 & $\mathrm{F}$ & $0.993(19)$ & 0.3333 & 0.6667 & $0.12406(10)$ & $0.0082(18)$ \\
& & & & & &
\end{tabular}

\subsection{Structural investigations: average} structure

For structural investigation, diffraction data of three crystals (A, B and C) of aravaite were collected. All crystals show distinct Bragg reflections which can be indexed using a trigonal unit cell (data for crystal A are listed in Table 2). Besides the Bragg reflections, one-dimensional diffuse intensities along $\mathbf{c}^{*}$ are visible in the diffraction pattern. Fig. 4 shows the reconstructed $(h 0 l)$ layer with one-dimensional diffuse intensities along $\mathbf{c}^{*}$ (crystal A). Data of the same crystal were used for the crystal structure refinement. This particular crystal exhibits the least intense diffuse scattering and, therefore, was most suited for analysis of the average structure. The other crystals (B and C) exhibit differences in the diffuse intensities. However, Bragg reflections conforming to the given unit cell were also found in crystals $\mathrm{B}$ and C. Refined lattice parameters were not significantly different from crystal A.

The average structure of aravaite was solved using direct methods (SIR2004; Burla et al., 2005). Subsequent least-squares $\left(\mathrm{CO}_{3}\right)^{2-}$. The intensity of this band is approximately half of the intensity of the band $v_{1}\left(\mathrm{PO}_{4}\right)^{3-}$. In stracherite the intensities of these two bands are roughly the same (Fig. 3).

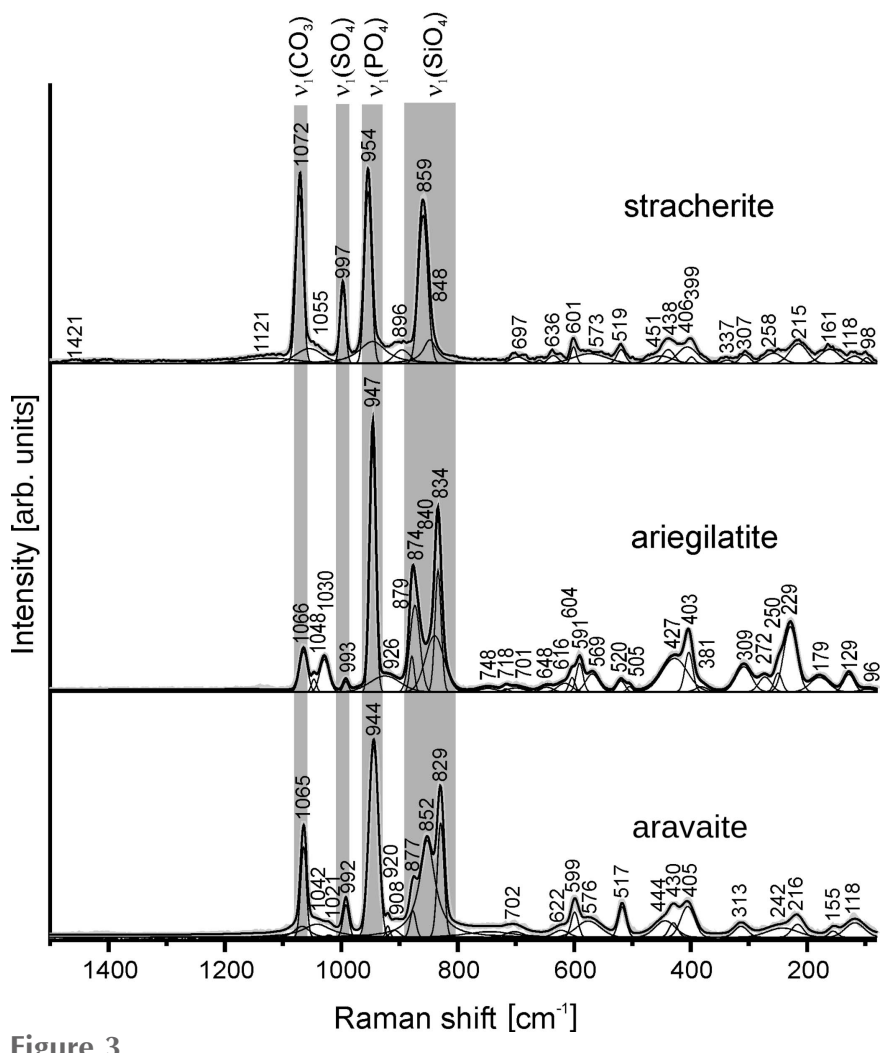

Figure 3

Raman spectra of stracherite, ariegilatite and aravaite. refinements were performed using the program Jana2006 (Petříček et al., 2014). Scattering coefficients were taken from International Tables for Crystallography, Volume C (Wilson,

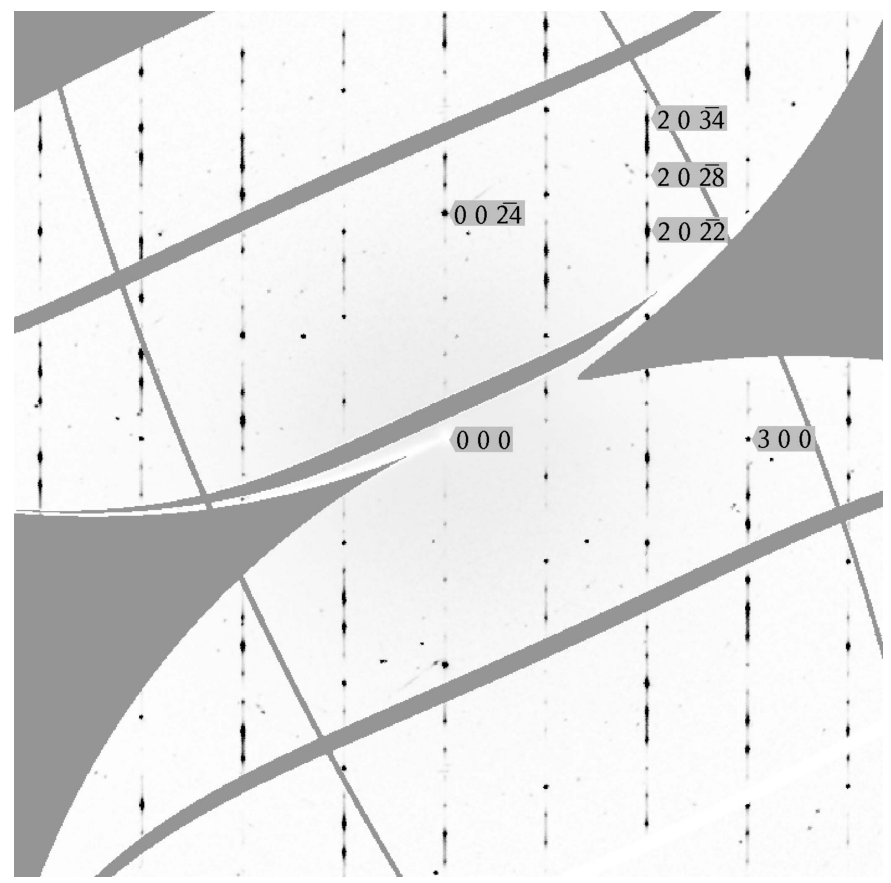

Figure 4

Reciprocal space layer $(h 0 l)$ of crystal A, as reconstructed from synchrotron diffraction data. The labelled group of reflections $(20 \overline{22}-$ $20 \overline{34}$ ) exhibits a characteristic pattern of one-dimensional diffuse scattering and is used as an example for comparing experimental and simulated data. 
Table 4

Anisotropic displacement parameters of aravaite.

\begin{tabular}{|c|c|c|c|c|c|c|c|}
\hline $\begin{array}{l}\text { Atom } \\
\text { site }\end{array}$ & $\begin{array}{l}\text { Atom } \\
\text { type }\end{array}$ & $U_{11}$ & $U_{22}$ & $U_{33}$ & $U_{12}$ & $U_{13}$ & $U_{23}$ \\
\hline $\mathrm{Ba} 1$ & $\mathrm{Ba}$ & $0.0142(3)$ & $0.0142(3)$ & 0.0135 (4) & $0.00711(16)$ & 0 & 0 \\
\hline $\mathrm{Ca} 1$ & $\mathrm{Ca}$ & $0.0017(5)$ & $0.0015(6)$ & $0.0164(7)$ & $0.0008(3)$ & $-0.0007(2)$ & $-0.0014(4)$ \\
\hline $\mathrm{Ca} 2$ & $\mathrm{Ca}$ & $0.0033(6)$ & $0.0028(5)$ & $0.0201(8)$ & $0.0016(3)$ & $-0.0010(4)$ & $-0.0005(2)$ \\
\hline $\mathrm{Ca} 3$ & $\mathrm{Ca}$ & $0.0023(5)$ & $0.0034(6)$ & $0.0119(7)$ & $0.0017(3)$ & $0.0006(2)$ & $0.0012(4)$ \\
\hline $\mathrm{Na} 3$ & $\mathrm{Na}$ & $0.0023(5)$ & $0.0034(6)$ & $0.0119(7)$ & $0.0017(3)$ & $0.0006(2)$ & $0.0012(4)$ \\
\hline$T 1$ & $\mathrm{Si}$ & $0.0003(5)$ & $0.0003(5)$ & $0.0058(9)$ & $0.0002(3)$ & 0 & 0 \\
\hline$T 3$ & $\mathrm{Si}$ & $0.0003(5)$ & $0.0003(5)$ & $0.0058(9)$ & $0.0002(3)$ & 0 & 0 \\
\hline$T 4$ & $\mathrm{P}$ & $0.0069(10)$ & $0.0069(10)$ & 0.0051 (14) & $0.0035(5)$ & 0 & 0 \\
\hline $\mathrm{O} 1$ & $\mathrm{O}$ & $0.022(2)$ & $0.022(2)$ & $0.010(3)$ & $0.013(2)$ & $-0.0006(10)$ & $0.0006(10)$ \\
\hline $\mathrm{O} 2$ & $\mathrm{O}$ & $0.014(2)$ & $0.014(2)$ & $0.008(4)$ & $0.0072(12)$ & 0 & 0 \\
\hline $\mathrm{O} 3$ & $\mathrm{O}$ & $0.0065(15)$ & 0.0035 (19) & $0.047(3)$ & $0.0017(10)$ & $-0.0052(10)$ & $-0.010(2)$ \\
\hline $\mathrm{O} 4$ & $\mathrm{O}$ & $0.013(2)$ & $0.013(2)$ & $0.005(4)$ & $0.0066(11)$ & 0 & 0 \\
\hline O6 & $\mathrm{O}$ & $0.021(3)$ & $0.021(3)$ & $0.012(4)$ & 0.0104 (14) & 0 & 0 \\
\hline O7 & $\mathrm{O}$ & $0.009(2)$ & $0.009(2)$ & $0.008(4)$ & $0.0046(11)$ & 0 & 0 \\
\hline $\mathrm{O} 8$ & $\mathrm{O}$ & $0.0023(18)$ & $0.0063(14)$ & $0.023(3)$ & $0.0011(9)$ & $0.0020(16)$ & $0.0010(8)$ \\
\hline O9 & $\mathrm{O}$ & $0.0129(15)$ & $0.0129(15)$ & $0.012(2)$ & $0.0092(18)$ & $-0.0013(8)$ & $0.0013(8)$ \\
\hline $\mathrm{F} 2$ & $\mathrm{~F}$ & $0.016(3)$ & $0.016(3)$ & $0.007(4)$ & $0.0079(14)$ & 0 & 0 \\
\hline F3 & $\mathrm{F}$ & $0.008(2)$ & $0.008(2)$ & 0.009 (3) & $0.0038(10)$ & 0 & 0 \\
\hline
\end{tabular}

1995). Atom coordinates, isotropic displacement parameters and site occupancies for the average structure of the new mineral are presented in Table 3, anisotropic displacement parameters in Table 4, and selected bond distances in Table 5.

Bond-valence sum calculations are used to evaluate the valence of anion sites and, therefore, to identify fluorine and oxygen positions (Altermatt \& Brown, 1985). The resulting structure model was refined using 85 parameters and 1291 independent reflections. Most of the atoms were described using anisotropic displacement parameters. Some atoms were modelled using isotropic displacement parameters, e.g. the sites with disorder such as $T 5, \mathrm{O} 11 / \mathrm{F} 1$. The notable high peak in the residual electron density is located $0.26 \AA$ from the O10 atom (at the $T 3$ tetrahedra) and does not represent a modellable atom position. The final $R 1$ value of the refinement is 0.082 , which is considerably larger than what we obtained in refinements of stracherite and ariegilatite (measured under comparable conditions, $R 1 \simeq 0.02$ ). We attribute the larger $R$ value, as well as the high residual electron density, to the stacking disorder, which obviously is present in the structure.

The structure of the mineral aravaite, $\mathrm{Ba}_{2} \mathrm{Ca}_{18}\left[\left(\mathrm{SiO}_{4}\right)_{6^{-}}\right.$ $\left.\left(\mathrm{PO}_{4}\right)_{3}\left(\mathrm{CO}_{3}\right)\right] \mathrm{F}_{3} \mathrm{O}$, can be described as a stacking of three different modules along [001]: T-layers $\left\{\mathrm{Ba}\left(\mathrm{PO}_{4}\right)_{1.5}\left(\mathrm{CO}_{3}\right)_{0.5}\right\}^{3.5-}$, triple antiperovskite (tAP) layers $\left\{\left(\mathrm{F}_{2} \mathrm{OCa}_{12}\right)\left(\mathrm{SiO}_{4}\right)_{4}\right\}^{4+}$ and single antiperovskite (sAP) layers $\left\{\left(\mathrm{FCa}_{6}\right)\left(\mathrm{SiO}_{4}\right)_{2}\right\}^{3+}$ (Fig. 1). The modules are stacked in the sequence of $\mathrm{T}-\mathrm{sAP}-\mathrm{T}-\mathrm{tAP}-\ldots$ This fragment of the sequence repeats three times within the unit cell. Along the $\mathbf{c}$ direction, the sum of all modules equals the sum of one unit cell of stracherite [three T-layers of $\left\{\mathrm{Ba}\left(\mathrm{PO}_{4}\right)_{1.5}\left(\mathrm{CO}_{3}\right)_{0.5}\right\}^{3.5-}$ and three sAP layers $\left.\left\{\left(\mathrm{FCa}_{6}\right)\left(\mathrm{SiO}_{4}\right)_{2}\right\}^{3+}\right]$ plus one unit cell of ariegilatite [three T-layers of $\left\{\mathrm{Ba}\left(\mathrm{PO}_{4}\right)_{1.5}\left(\mathrm{CO}_{3}\right)_{0.5}\right\}^{3.5-}$ and three tAP layers $\left.\left\{\left(\mathrm{F}_{2} \mathrm{OCa}_{12}\right)\left(\mathrm{SiO}_{4}\right)_{4}\right\}^{4+}\right]$ (Fig. 1).

Comparing the structural model of aravaite to the structures of stracherite and ariegilatite, we can say that the refinement is essentially correct and represents a valid model of the average structure, even though the $R 1$ value seems not to be satisfying considering the refinement using synchrotron data.

The new mineral aravaite has six $\mathrm{T}$ layers of $\left\{\mathrm{Ba}\left(\mathrm{PO}_{4}\right)_{1.5}\left(\mathrm{CO}_{3}\right)_{0.5}\right\}^{3.5-}$, composed of $\mathrm{BaO}_{6}$ octahedra, which are connected by two symmetry-independent $\mathrm{PO}_{4}$ tetrahedra. One of the tetrahedra (T4) has an average $\mathrm{P}-\mathrm{O}$ distance of $1.549 \AA$, the other (T5) shows smaller distances with an average of $1.472 \AA$. Therefore, it can be assumed that substitution by $\mathrm{CO}_{3}$ groups takes place on T5. Occupational and positional disorder of $\mathrm{PO}_{4} / \mathrm{CO}_{3}$ at the $T 5$ site results in unusual small bond distances with values somewhat intermediate between optimal $\mathrm{P}-\mathrm{O} \simeq$ $1.53 \AA$ and $\mathrm{C}-\mathrm{O} \simeq 1.28 \AA$ bond lengths (Shannon, 1976; Huminicki \& Hawthorne, 2002; Krivovichev, 2009). This substitution mechanism was found in stracherite and is discussed by Galuskin et al. (2018b).

The T-layers in stracherite and ariegilatite also contain two $\mathrm{PO}_{4}$ tetrahedra; however, in these structures they are related by symmetry. In ariegilatite, the $\mathrm{P}-\mathrm{O}$ distances average an unremarkable $1.547 \AA$, whereas in stracherite smaller values $[3 \times 1.4722(2)$ and $1.5400(4) \AA]$ occur due to substitution of $\mathrm{CO}_{3}\left(40 \%\right.$ of $\mathrm{PO}_{4}$ is replaced by $\left.\mathrm{CO}_{3}\right)$. The planar $\left(\mathrm{CO}_{3}\right)^{2-}$ groups are not observed in the base plane of substituted tetrahedra, as expected, but statistically distributed over three equivalent positions, parallel to three faces. This was confirmed by structural refinement and Raman spectroscopy investigations (Galuskin et al., 2018b). The substitution of $\mathrm{CO}_{3}$ groups for $\mathrm{PO}_{4}$ tetrahedra in stracherite results in cation and anion disorder, characterized by splitting of $\mathrm{Ca}$ and $\mathrm{O}$ atom in adjacent layer. However, in aravaite we cannot model this local environment as detailed as in stracherite, because of the stacking fault disorder which limits the quality of the refinement. Nevertheless, analysis of the oxygen atoms surrounding $T 5$, shows that the $\mathrm{O} 1$ site is depleted ( $\sim 12 \%$ vacancies), whereas $\mathrm{O} 2$ exhibits full occupancy. This is in agreement with the $\mathrm{CO}_{3}$ substitution mechanism observed in stracherite. As no additional peaks of electron density were observed in the environment of $T 5$, carbon was placed together with $\mathrm{P}$ on the T5 site. The small amount of sulfur ( $0.24 \mathrm{apfu})$ is assumed to be refined in sum with phosphorus due to the similar scattering power. Occupational parameters were refined to $54 \%$ for $\mathrm{P}$ and $46 \%$ for C, supporting the results of the chemical analysis (Table 1) and charge density calculation. The refined O1 vacancies account for $36 \%$ of $\mathrm{CO}_{3}$ triangles only. The difference is probably caused by inaccuracy of the refinement of the involved occupancies.

The single antiperovskite (sAP) layers are built of $\mathrm{F} \mathrm{Ca}_{6}$ octahedra and $\mathrm{SiO}_{4}$ tetrahedra. They are equivalent to those found in stracherite and gazeevite. The same sAP layers can 
Table 5

Distances and bond valences.

\begin{tabular}{|c|c|c|}
\hline Bonds & $\begin{array}{l}\text { Distance } \\
(\AA)\end{array}$ & $\begin{array}{l}\text { Bond valence } \\
\text { contribution }\end{array}$ \\
\hline $\mathrm{Ba} 1-\mathrm{O} 1 \times 3$ & $2.864(4)$ & 0.181 \\
\hline $\mathrm{Ba} 1-\mathrm{O} 3 \times 3$ & $3.251(5)$ & 0.073 \\
\hline $\mathrm{Ba} 1-\mathrm{O} 8 \times 3$ & $3.398(5)$ & 0.049 \\
\hline $\mathrm{Ba} 1-\mathrm{O} 9 \times 3$ & $2.815(3)$ & 0.239 \\
\hline Average & 3.082 & \\
\hline BVS & & 1.628 \\
\hline $\mathrm{Ca} 1-\mathrm{O} 2$ & $2.418(4)$ & 0.294 \\
\hline $\mathrm{Ca} 1-\mathrm{O} 7$ & $2.359(4)$ & 0.347 \\
\hline $\mathrm{Ca} 1-\mathrm{O} 8 \times 2$ & $2.395(5)$ & 0.314 \\
\hline $\mathrm{Ca} 1-\mathrm{O} 9 \times 2$ & $2.464(3)$ & 0.261 \\
\hline $\mathrm{Ca} 1-\mathrm{F} 3$ & $2.546(4)$ & 0.148 \\
\hline Average & 2.434 & \\
\hline BVS & & 1.939 \\
\hline $\mathrm{Ca} 2-\mathrm{O} 1 \times 2$ & $2.563(4)$ & 0.173 \\
\hline $\mathrm{Ca} 2-\mathrm{O} 3 \times 3$ & $2.971(6)$ & 0.066 \\
\hline $\mathrm{Ca} 2-\mathrm{O} 4$ & $2.393(4)$ & 0.316 \\
\hline $\mathrm{Ca} 2-\mathrm{O} 6$ & $2.285(3)$ & 0.423 \\
\hline $\mathrm{Ca} 2-\mathrm{F} 2$ & $2.5507(12)$ & 0.147 \\
\hline Average & 2.342 & \\
\hline $\mathrm{BVS}^{\circ}$ & & 1.996 \\
\hline $\mathrm{Ca} 3-\mathrm{O} 5 \times 3$ & $2.515(5)$ & 0.227 \\
\hline $\mathrm{Ca} 3-\mathrm{O} 8$ & $2.616(5)$ & 0.173 \\
\hline $\mathrm{Ca} 3-\mathrm{O} 10$ & $2.2170(16)$ & 0.509 \\
\hline $\mathrm{Ca} 3-\mathrm{O} 11$ & $2.3317(12)$ & 0.196 \\
\hline $\mathrm{Ca} 3-\mathrm{F} 1$ & $2.3317(12)$ & 0.126 \\
\hline $\mathrm{Ca} 3-\mathrm{F} 3$ & $2.451(4)$ & 0.192 \\
\hline Average & 2.390 & \\
\hline BVS & & 2.174 \\
\hline $\mathrm{Na} 3-\mathrm{O} 5 \times 3$ & $2.515(5)$ & 0.146 \\
\hline $\mathrm{Na} 3-\mathrm{O} 8$ & $2.616(5)$ & 0.111 \\
\hline $\mathrm{Na} 3-\mathrm{O} 10$ & $2.2170(16)$ & 0.327 \\
\hline $\mathrm{Na} 3-\mathrm{O} 11$ & $2.3317(12)$ & 0.126 \\
\hline $\mathrm{Na} 3-\mathrm{F} 1$ & $2.3317(12)$ & 0.081 \\
\hline $\mathrm{Na} 3-\mathrm{F} 3$ & $2.451(4)$ & 0.123 \\
\hline Average & 2.390 & \\
\hline BVS & & 1.395 \\
\hline$T 1-\mathrm{O} 5 \times 3$ & $1.621(4)$ & 1.008 \\
\hline$T 1-\mathrm{O} 7$ & $1.636(8)$ & 0.968 \\
\hline Average & 1.625 & \\
\hline BVS & & 3.992 \\
\hline$T 2-\mathrm{O} 3 \times 3$ & $1.607(5)$ & 1.047 \\
\hline$T 2-\mathrm{O} 6$ & $1.606(9)$ & 1.049 \\
\hline Average & 1.607 & \\
\hline BVS & & 4.191 \\
\hline$T 3-\mathrm{O} 8 \times 3$ & $1.610(4)$ & 1.038 \\
\hline T3-O10 & $1.747(7)$ & 0.718 \\
\hline Average & 1.644 & \\
\hline BVS & & 3.831 \\
\hline$T 4-\mathrm{O} 4$ & $1.545(8)$ & 1.214 \\
\hline$T 4-\mathrm{O} 9 \times 3$ & $1.551(3)$ & 1.197 \\
\hline Average & 1.549 & \\
\hline BVS & & 4.803 \\
\hline$T 5 p-\mathrm{O} 1 \times 3$ & $1.475(4)$ & 1.271 \\
\hline$T 5 \mathrm{p}-\mathrm{O} 2$ & $1.463(9)$ & 1.504 \\
\hline Average & 1.472 & \\
\hline BVS & & 5.316 \\
\hline$T 5 \mathrm{c}-\mathrm{O} 1 \times 2$ & $1.475(4)$ & 1.271 \\
\hline$T 5 c-O 2$ & $1.463(9)$ & 1.504 \\
\hline Average & 1.471 & \\
\hline BVS & & 4.046 \\
\hline
\end{tabular}

be found in the other minerals of the zadovite group: zadovite and aradite. However in these minerals, $\mathrm{SiO}_{4}$ tetrahedra are partly substituted by phosphate and vanadate tetrahedra, respectively.

The same kind of layers was described earlier for a number of minerals exhibiting elements of hexagonal antiperovskite structures (Sokolova et al., 1999; Sokolova \& Hawthorne, 2001; Krivovichev, 2007).

Employing bond-valence sum calculations, fluorine and oxygen are assigned to anion sites in the tAP layers (Table 5). Fluorine resides on the two outer octahedral sites (Fig. 1), whereas the anion site in the central octahedra is shared by fluorine and oxygen. In contrast to aravaite, ariegilatite (and nabimusaite) exhibit an ordered anion distribution, with oxygen residing in the centre and fluorine on the two outer octahedral sites. For charge compensation, the $\mathrm{Ca}$ sites ( $\mathrm{Ca} 3$, Table 3) coordinating the inner octahedral site are partly substituted by Na. Similar behaviour is already observed in two other compounds: in arctite, $\mathrm{BaCa}_{7} \mathrm{Na}_{5}\left(\mathrm{PO}_{4}\right)_{6} \mathrm{~F}_{3}$ (Sokolova et al., 1984; Sokolova \& Hawthorne, 2001), all three positions are occupied by $\mathrm{F}$ and in the isostructural synthetic compound $\mathrm{Ca}_{5.45} \mathrm{Li}_{3.55}\left[\mathrm{SiO}_{4}\right]_{3} \mathrm{O}_{0.45} \mathrm{~F}_{1.55}$ (Krüger, 2010), the central anion position is also shared by $\mathrm{O}$ and $\mathrm{F}$.

\section{Stacking faults and modelling of disorder}

The crystal structure of aravaite can be described as an alternating sequence of ariegilatite (T-tAP) and stracherite (T-sAP) blocks. Considering the presence of one-dimensional diffuse scattering, an obvious explanation is the stacking faults which disturb the ordered (alternating) sequence of ariegilatite and stracherite blocks. This hypothesis is further supported by the fact that both structures (ariegilatite and stracherite) are formed in similar conditions and are even observed intergrown (Fig. 2b).

In order to test the aforementioned hypothesis of disorder within the sequence of T-tAP and T-sAP blocks, structural models of these two blocks were prepared starting from the respective structures. The $c$ lattice parameter of the stracherite block (T-sAP) is $8.35 \AA\left(\simeq c_{\text {sta }} / 3\right)$, and for the ariegilatite block it is $13.74 \AA\left(\simeq c_{\text {ari }} / 3\right)$. The model of the stracherite block contains 28 atoms, whereas the model of the ariegilatite block includes 46 atoms. The earlier mentioned disorder $\left(\mathrm{CO}_{3}\right.$ substitution) was neglected. By stacking T-tAP or T-sAP blocks only, the structures of ariegilatite or stracherite are obtained, respectively. Stacking these blocks alternatingly results in the structure of aravaite. Stacking has to be done by using a vector of $\left(\frac{2}{3}, \frac{1}{3}, c_{\text {block }}\right)$ to emulate the $R$-centring of the structures and to keep the structure of the interface unchanged. The software DISCUS (version 5.14; Proffen \& Neder, 1999; Neder \& Proffen, 2008) was utilized to create stacking sequences with different degrees of disorder. A Markov chain growth disorder model was employed, which is defined by a right stochastic matrix containing the transition probabilities between adjacent blocks (e.g. $P_{\text {sta-ari }}$ is the 
probability for an ariegilatite block following a stracherite block):

$$
M=\left(\begin{array}{ll}
P_{\text {sta-sta }} & P_{\text {sta-ari }} \\
P_{\text {ari-sta }} & P_{\text {ari-ari }}
\end{array}\right)=\left(\begin{array}{cc}
1-\alpha & \alpha \\
1-\alpha-\beta & \alpha+\beta
\end{array}\right) .
$$

The growth parameters $\alpha$ and $\beta$ are related to the elements of the stochastic matrix as shown above (for details, see e.g., Welberry, 2004; Neder \& Proffen, 2008).

In this case both blocks have to be present in the same amount (constrained by chemical composition). Consequently, $\beta=1-2 \alpha$, because of the known relation between $\alpha, \beta$ and the concentration of block types. The growth parameter $\alpha$ represents the probability of a change in the block type, whereas $\beta$ denotes the correlation between neighbouring blocks.

A series of models for different growth parameters was created. Each model was simulated 750 times using 25000 blocks. X-ray scattering was calculated using a Fourier transform of each simulation as described by Neder \& Proffen (2008) and subsequently the line profiles of all 750 simulations were summed up. The $20 l$ intensity profiles for models with negative to zero correlation are shown in Fig. 5. Simulations with positive correlation (ordering towards domains of stracherite and ariegilatite) are shown in Fig. 6. For a qualitative comparison of the diffuse scattering a part of the $20 l$ line was chosen. Between $l=-37$ and $l=-17$ some characteristic diffuse intensities can be observed in the experimental data of crystal A (Figs. 4 and 7). The highest intensities are located between the -34 and -31 Bragg reflections. However, between all neighbouring pairs of Bragg reflections diffuse scattering can be observed. A minimum is located at the right side of -28 , towards -25 the intensity is slightly increasing. The minor peak at circa $l=-20$ is most likely an 'alien' reflection, belonging to another crystal grain. The simulations (shown in Fig. 5) explain all significant features of the diffuse

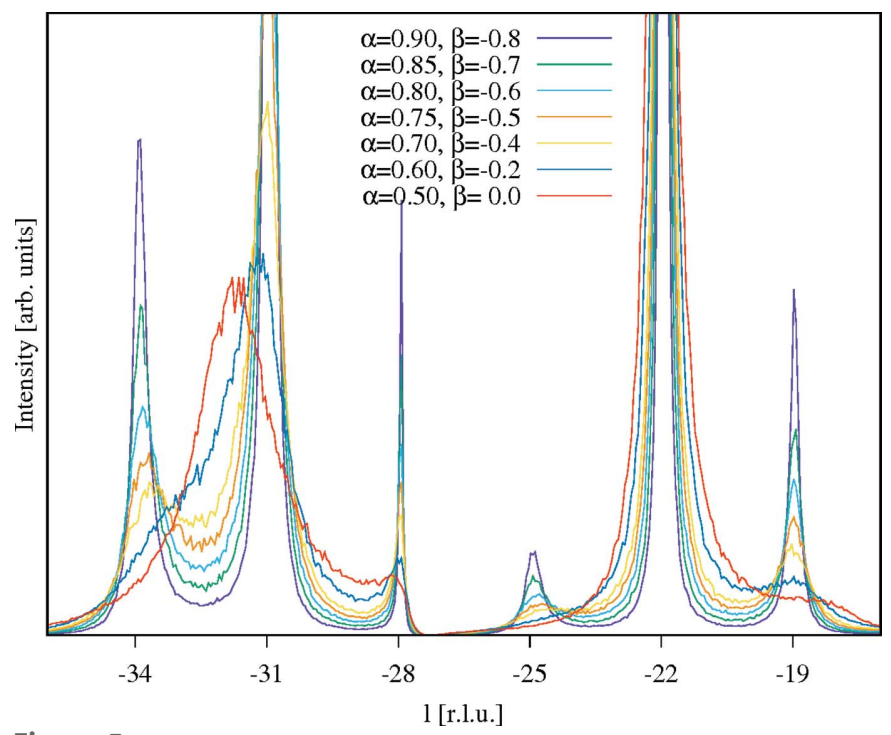

Figure 5

Intensity distribution along the reciprocal space line $20 l$ obtained from simulations with $\alpha=0.9, \ldots, 0.5$ (r.l.u. is reciprocal lattice units). This series shows the effect of increasing disorder. scattering observed in Fig. 7. However, none of the simulated growth parameters result in a perfect match. For example, none of the simulations reproduce the observed intensity relations between $-34,-28$ and -25 . A certain range of $\alpha$ seems to be required to obtain a better fit. Measurements on several crystals have shown that the degree of order is quite variable; therefore, also within a single crystal variations are likely to occur.

The intensity distribution along $20 l$ in crystals B and C is different. Fig. 8 shows that crystal B exhibits the same features as crystal A (Fig. 7); however, the intensities on -28 and -25 are reduced, whereas -31 seems stronger compared with -34 . This is what can be expected from increased disorder (compare with Fig. 5). Crystal $\mathrm{C}$ shows additional peaks (Fig. 8), which at a first glance suggest a superstructure. A more detailed investigation shows that the strongest of them may be explained by the existence of ordered domains of ariegilatite. The simulations for large positive correlation (shown in Fig. 6) produce intensities on positions corresponding to the lattices of stracherite and ariegilatite, because increasing correlations result in larger domains of stracherite and ariegilatite. Fig. 9 shows the diffuse scattering on $20 l$ for $\alpha=0.9,0.5$ and 0.1. Simulations of the ordered structures of ariegilatite, stracherite and aravaite were used to assign peaks of the disordered simulation ( $\alpha=0.9$ and 0.1$)$ to the respective structures. Reciprocal lattice units (r.l.u.) refer to $c$ of aravaite. With the guidance of Fig. 9, the additional reflections of crystal $\mathrm{C}$ (Fig. 8) may be explained. The intensity at $l=-32.1$ occurs at the same position where a peak of ariegilatite domains would be expected. The same is true for the small peak at -17.7. However, the intense stracherite peak expected at -21.1 is not visible in the data of crystal C. Also, the stracherite peak at -29 (Fig. 9) does not fit to the position of a weak intensity in Fig. 8 (at $l=-29.5$ ). Two more small

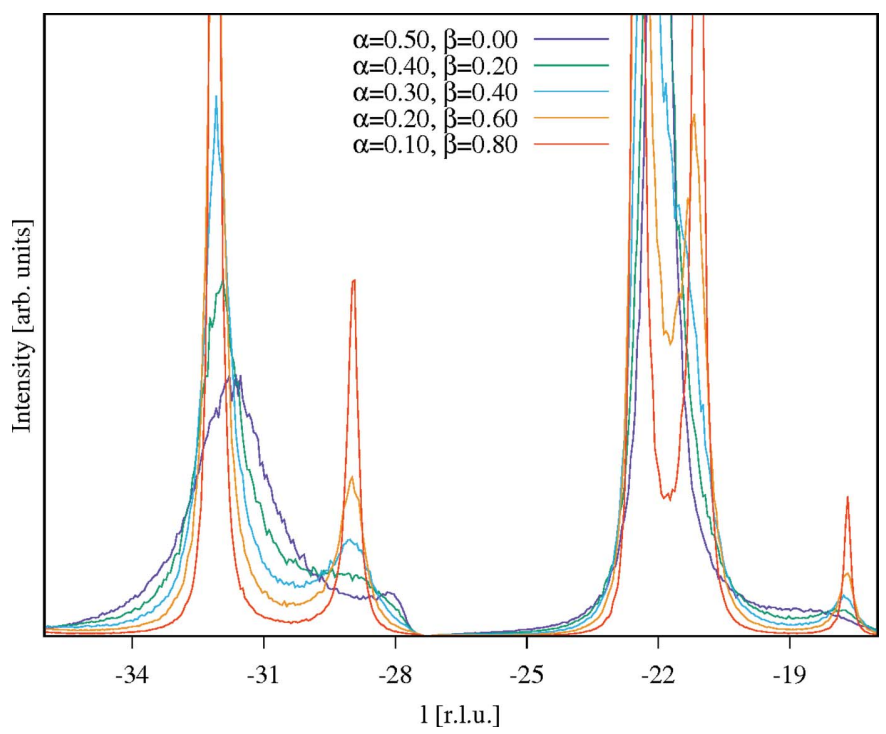

Figure 6

Intensity distribution along the reciprocal space line $20 l$ obtained from simulations with positive correlations $(\beta=0.0, \ldots, 0.8)$ (r.l.u. is reciprocal lattice units). This series shows the effect of increasing order towards larger domains of stracherite and ariegilatite. 
intensities at -23.7 and -22.4 cannot be explained. One possible reason for these observations is that besides ariegilatite domains, domains of a stracherite-enriched superstructure exist. Another explanation for the missing intensity of the stracherite peaks may be a deviation in the chemical composition of the specific grain. However, without further simulations and experimental work, such as transmission electron microscopy, this is speculation. The fact is that crystal $\mathrm{C}$ additionally shows all features of a fairly disordered crystal (such as crystal B). Therefore, it has to contain a large variation in its disorder.

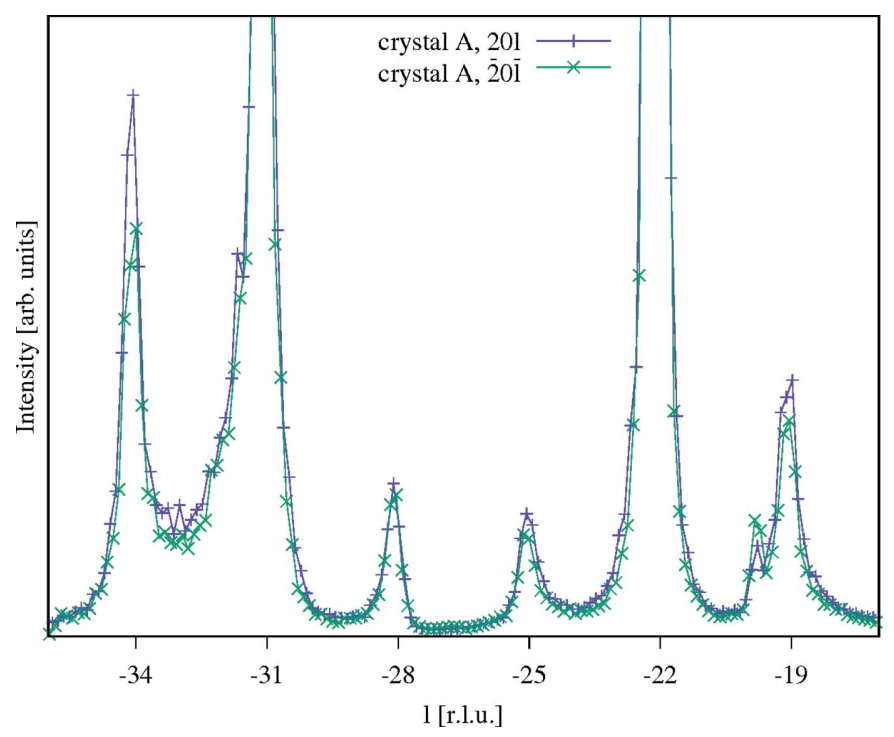

Figure 7

Intensity distribution along reciprocal space line $20 l$ of crystal A (r.l.u. is reciprocal lattice units). Two symmetry-equivalent lines are shown.

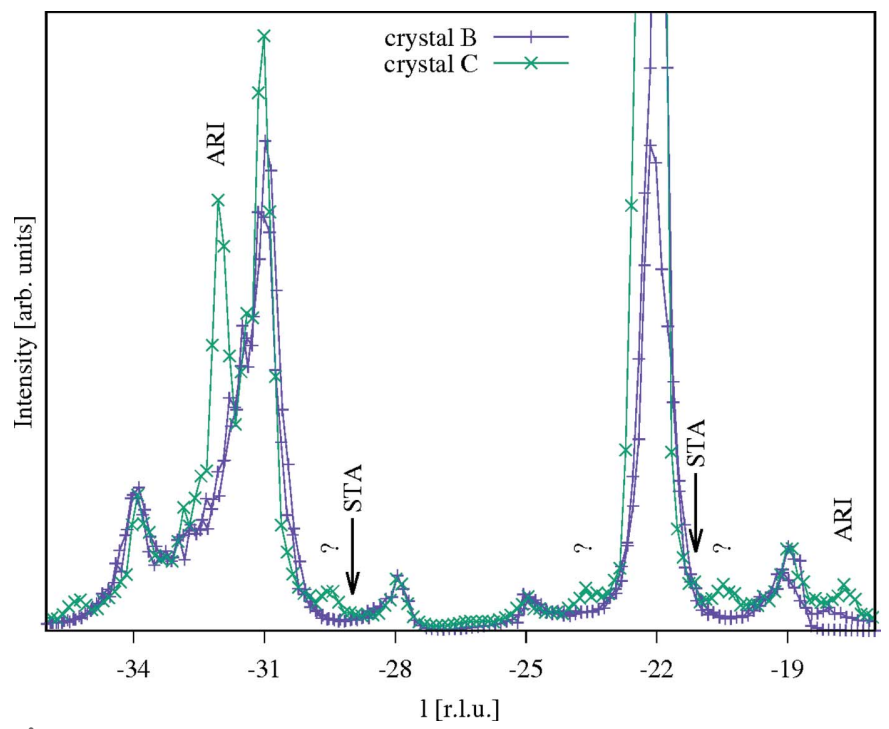

Figure 8

Intensity distribution along reciprocal space line $20 l$ of crystal B and C (r.l.u. is reciprocal lattice units). For crystal B two symmetry-equivalent lines are drawn. Crystal $C$ exhibits extra reflections, the strongest of which can be explained by ariegilatite (ARI) domains. Positions at which stracherite (STA) peaks could be expected are indicated. Compare with the simulations shown in Fig. 9.

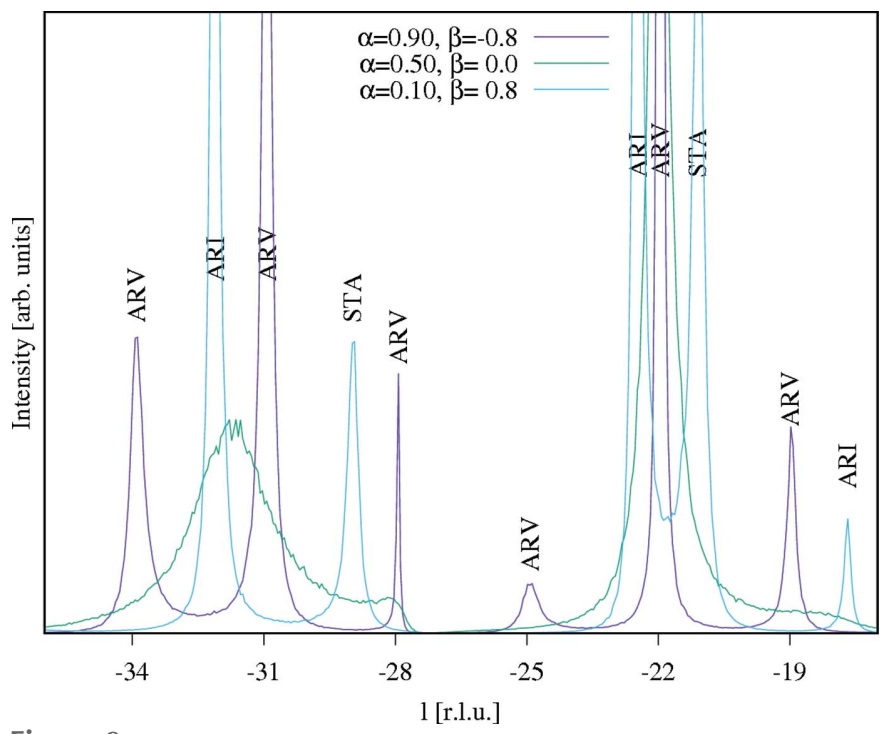

Figure 9

The intensity distribution along $20 l$ for three different simulations $(\alpha=$ $0.9,0.5$ and 0.1 ) (r.l.u. is reciprocal lattice units). The first simulation is close to an ordered structure of aravaite. The second exhibits a random sequence $(\beta=0)$, and the third a strong positive correlation, which results in domains of stracherite (STA) and ariegilatite (ARI). Peaks are labelled with the phase of major intensity contribution.

Nonetheless, the simulations prove that the diffuse scattering in aravaite is caused by a faulty sequence of ariegilatite and stracherite modules. Furthermore, the simulations show that disorder has a major impact on the intensities of Bragg reflections. This can be seen in the rather high- $R$ values and high residual electron density of the structure refinement.

\section{Conclusion}

Aravaite brings another structure type into the list of known intercalated antiperovskites. Therefore, a new group is needed for their classification, as it fits neither into the nabimusaite group nor into the zadovite group. A mixed structures group within the arctite supergroup was proposed by Galuskin $e t$ al. (2018a). Similar mixed structures may exist between other members of the nabimusaite and zadovite group.

The observed disorder by stacking faults is an interesting case with two layers of different thickness. The presented disorder model can be applied to similar cases, which may exist within the arctite supergroup. It could also be adapted to cases with an unequal ratio of the different modules.

One interesting question is to what extent of the disorder a meaningful average structure model can be refined from Bragg diffraction data. In this case, the structure refinement of the most ordered crystal (least-diffuse intensities) still results in a complete structure model. However, limits of the model become visible. The details of the $\mathrm{CO}_{3}$ substitution could not be revealed as detailed as in ordered stracherite. Furthermore, some anisotropic displacement parameters became extreme or even physically meaningless. A test refinement with crystal B resulted in an increased $R 1$ of more than 0.12 with deteriorated quality of the structure model. However, the basic structure can still be derived. 


\section{Acknowledgements}

HK and BK acknowledge help from V. Goettgens and K. Zöll during the synchrotron experiments. HK also acknowledges the help of R. B. Neder, who provided very useful DISCUS example files.

\section{Funding information}

The following funding is acknowledged: the research leading to these results has received funding from the European Union's Horizon 2020 research and innovation programme under grant agreement No. 730872, project CALIPSOplus; the geological investigations were partly supported by the National Science Centre of Poland, grant No. 2016/23/B/ST10/ 00869.

\section{References}

Altermatt, D. \& Brown, I. D. (1985). Acta Cryst. B41, 240-244.

Bentor, Y. K. (1960). Editor. Israel. In Lexique Stratigraphique International, Asie, Vol. III, Ch. 10.2. Paris: CNRS.

Burla, M. C., Caliandro, R., Camalli, M., Carrozzini, B., Cascarano, G. L., De Caro, L., Giacovazzo, C., Polidori, G. \& Spagna, R. (2005). J. Appl. Cryst. 38, 381-388.

Estermann, M. A. \& Steurer, W. (1998). Phase Transitions, 67, 165195.

Ferraris, G., Makovicky, E. \& Merlino, S. (2004). Crystallography of Modular Materials. New York: Oxford University Press Inc.

Gäbler, F. \& Niewa, R. (2007). Inorg. Chem. 46, 859-865.

Galuskin, E. V., Galuskina, I. O., Krüger, B. \& Krüger, H. (2018a). Abstr. XXII Meet. Int. Mineral. Assoc., 13-17 August 2018, Melbourne, Australia, pp. 523-524.

Galuskin, E. V., Gfeller, F., Armbruster, T., Galuskina, I. O., Vapnik, Y., Murashko, M., Włodyka, R. \& Dzierżanowski, P. (2015a). Mineral. Mag. 79, 1061-1072.

Galuskin, E. V., Gfeller, F., Galuskina, I. O., Armbruster, T., Krzątała, A., Vapnik, Y., Kusz, J., Dulski, M., Gardocki, M., Gurbanov, A. G. \& Dzierżanowski, P. (2017). Mineral. Mag. 81, 499-513.

Galuskin, E. V., Gfeller, F., Galuskina, I. O., Pakhomova, A., Armbruster, T., Vapnik, Y., Włodyka, R., Dzierżanowski, P. \& Murashko, M. (2015b). Mineral. Mag. 79, 1073-1087.

Galuskin, E. V., Krüger, B., Galuskina, I. O., Krüger, H., Vapnik, Y., Pauluhn, A. \& Olieric, V. (2018b). Am. Mineral. 103, 1699-1706.

Galuskin, E. V., Krüger, B., Galuskina, I. O., Krüger, H., Vapnik, Y., Wojdyla, J. A. \& Murashko, M. (2018c). Minerals, 8, 109.
Galuskina, I. O., Gfeller, F., Galuskin, E. V., Armbruster, T., Vapnik, Ye, Dulski, M., Gardocki, M., Jeżak, L. \& Murashko, M. (2018). Mineral. Mag. https://doi.org/10.1180/minmag.2017.081.095

Galuskina, I. O., Vapnik, Y., Lazic, B., Armbruster, T., Murashko, M. \& Galuskin, E. V. (2014). Am. Mineral. 99, 965-975.

Gross, S. (1977). The Mineralogy of the Hatrurim Formation, Israel. Bulletin 70. Jerusalem: Geological Survey of Israel.

Huminicki, D. M. C. \& Hawthorne, F. C. (2002). Rev. Mineral. Geochem. 48, 123-253.

Kabsch, W. (2010). Acta Cryst. D66, 125-132.

Krivovichev, S. V. (2007). Z. Kristallogr. 223, 109-113.

Krivovichev, S. V. (2009). Structural Crystallography of Inorganic Oxysalts. New York: Oxford University Press Inc.

Krüger, H. (2010). Z. Kristallogr. Cryst. Mater. 225, 418-424.

Mitchell, R. H., Welch, M. D. \& Chakhmouradian, A. R. (2017). Mineral. Mag. 81, 411-461.

Neder, R. B. \& Proffen, T. (2008). Diffuse Scattering and Defect Structure Simulations: A Cook Book Using the Program DISCUS. New York: Oxford University Press Inc.

Petříček, V., Dušek, M. \& Palatinus, L. (2014). Z. Kristallogr. Cryst. Mater. 229, 345-352.

Proffen, Th. \& Neder, R. B. (1999). J. Appl. Cryst. 32, 838-839.

Rigaku (2016). CrysAlisPro. Rigaku Oxford Diffraction Ltd, Yarnton, Oxfordshire, England.

Schneider, C. A., Rasband, W. S. \& Eliceiri, K. W. (2012). Nat. Methods, 9, 671-675.

Shannon, R. D. (1976). Acta Cryst. A32, 751-767.

Sokol, E. V., Novikov, I. S., Zateeva, S. N., Sharygin, V. V. \& Vapnik, Y. (2008). Dokl. Earth Sci. 420, 608-614.

Sokolova, E. \& Hawthorne, F. C. (2001). Can. Mineral. 39, 12751294.

Sokolova, E. V., Kabalov, Yu. K., Ferraris, G., Schneider, J. \& Khomyakov, A. P. (1999). Can. Mineral. 37, 83-90.

Sokolova, E. V., Yamnova, N. A., Egorov-Tismenko, Y. K. \& Khomyakov, A. P. (1984). Dokl. Akad. Nauk SSSR, 274, 78-83.

Vapnik, Y., Sharygin, V. V., Sokol, E. V. \& Shagam, R. (2007). Rev. Eng. Geol. 18, 1-21.

Waltersperger, S., Olieric, V., Pradervand, C., Glettig, W., Salathe, M., Fuchs, M. R., Curtin, A., Wang, X., Ebner, S., Panepucci, E., Weinert, T., Schulze-Briese, C. \& Wang, M. (2015). J. Synchrotron Rad. 22, 895-900.

Welberry, T. R. (2004). Diffuse X-ray Scattering and Models of Disorder. New York: Oxford University Press Inc.

Wilson, A. J. C. (1995). International Tables for Crystallography, Volume C: Mathematical, Physical and Chemical Tables. Dordrecht, Boston, London: Kluwer Academic Publishers.

Wojdyla, J. A., Kaminski, J. W., Panepucci, E., Ebner, S., Wang, X., Gabadinho, J. \& Wang, M. (2018). J. Synchrotron Rad. 25, 293303. 